\author{
Klaudia Sychta, Aneta SŁomka, Elżbieta Kuta \\ Zakład Cytologii i Embriologii Roślin \\ Instytut Botaniki \\ Wydziat Biologii \\ Uniwersytet Jagielloński \\ Gronostajowa 9, 30-387 Kraków \\ E-mail: klaudia.michno@doctoral.uj.edu.pl
}

\title{
KULTURY ZAWIESINOWE KOMÓREK JAKO MODEL DO BADANIA TOLERANCJI ROŚLIN NA METALE CIEŻZIEIE*
}

\section{WSTEP}

Badania nad tolerancja roślin na metale ciężkie (gęstość powyżej $5 \mathrm{~g} / \mathrm{cm}^{3}$ ) obecne w glebie sa prowadzone od kilku dekad. Zanieczyszczenia gleby sa poważnym problemem w skali światowej ze względu na ogromny wpływ na mikroorganizmy, rośliny, zwierzęta oraz pośrednio lub bezpośrednio na zdrowie i życie człowieka (AGBOGIDI i współaut. 2013). Pierwiastki pobierane i wykorzystywane przez rośliny można podzielić na metale niezbędne w metabolizmie roślin, do których należą: $\mathrm{Zn}, \mathrm{Mn}, \mathrm{Cu}, \mathrm{Ni}, \mathrm{Fe}$; pobierane w ilościach ponadprogowych sa toksyczne. Natomiast pierwiastki balastowe: $\mathrm{Cd}, \mathrm{Pb}, \mathrm{Hg}, \mathrm{Al}$, Tl, As, niewykorzystywane w metabolizmie roślin, sa dla roślin toksyczne nawet w niewielkich ilościach (SIWEK 2008a i cyt. tam lit.). Różne są źródła metali ciężkich w glebie; moga być (i) naturalne (gleby orogeniczne), powstałe wskutek np. wietrzenia skał, erupcji wulkanów lub (ii) antropogeniczne, spowodowane przez różne gałęzie przemysłu, będące najczęstszym źródłem zanieczyszczeń (CEGIEŁKOWSKA i współaut. 2015). Większość tego typu zanieczyszczeń nie jest wymywanych $z$ gleby i pozostaje w niej bardzo długo (PADMAVATHIAMMA i LI 2007), a nieorganiczne związki metali ciężkich są bardzo słabo biodegradowalne (WUANA i OKIEIMEN 2011). Tereny zanieczyszczone metalami ciężkimi sa kolonizowane przez tzw. metalolubne rośliny (odporne ekotypy), określane również jako metalofity, którym nadawano różne rangi taksonomiczne (odmiany, podgatunki, gatun- ki). Taksony te reprezentuja różny stopień tolerancji, niektóre sa nawet tzw. hiperakumulatorami metali. Metalofity występują w 34 niespokrewnionych rodzinach roślin okrytonasiennych. Do rodzin bogatych w gatunki odporne na metale ciężkie należą: Asteraceae, Brassicaceae, Caryophyllaceae, Plumbaginaceae, Poaceae, Violaceae (BOTHE 2011). Szczególnie wysoka frekwencją metalofitów charakteryzuje się rodzaj Viola L. (Ryc. 1), w obrębie którego występuja metalofity obligatoryjne (wyłacznie na glebach metalonosnych), metalofity fakultatywne (na glebach niezanieczyszczonych i metalonośnych) oraz tzw. metalofity przygodne (nie tworza trwałych populacji na glebach metalonośnych) (SŁOMKA i KUTA 2015). W zależności od typu gleby, skład florystyczny jest różny. Gleby galmanowe Europy, bogate w $\mathrm{Zn} / \mathrm{Pb}$, kolonizowane sa np. przez Silene vulgaris ssp. angustifolia, Armeria elongata var. halleri, Biscutella laevigata, Thlaspi caerulescens, Viola lutea ssp. calaminaria, $V$. lutea ssp. westfalica, gleby serpentynowe o wysokich stężeniach $\mathrm{Ni} / \mathrm{Cr} / \mathrm{Fe} / \mathrm{Mg}$ - przez endemiczne gatunki: Alyssum markgrafii, Minuartia baldaccii, Viola dukadjinica, Thlaspi goesingense, gleby miedzionośne - przez kilka gatunków traw (np. Agrostis stolonifera, Festuca rubra), a gleby arsenowe np. przez endemiczne gatunki Viola arsenica, V. allchariensis (STEVANOVIĆ i współaut. 2003, 2010; ROSTAŃSKI i współaut. 2015; SŁOMKA i współaut. 2015; SZAREK-ŁUKASZEWSKA i współaut. 2015).

Organizmy żywe wykazują pewien poziom tolerancji na metale. Jest to tzw. tolerancja

Słowa kluczowe: Kultura zawiesinowa, metale ciężkie, metalofity, żywotność komórek, programowana śmierć komórki

*Artykuł powstał w ramach projektu badawczego nr 2017/27/N/N28/00949 finansowanego ze środków Narodowego Centrum Nauki 

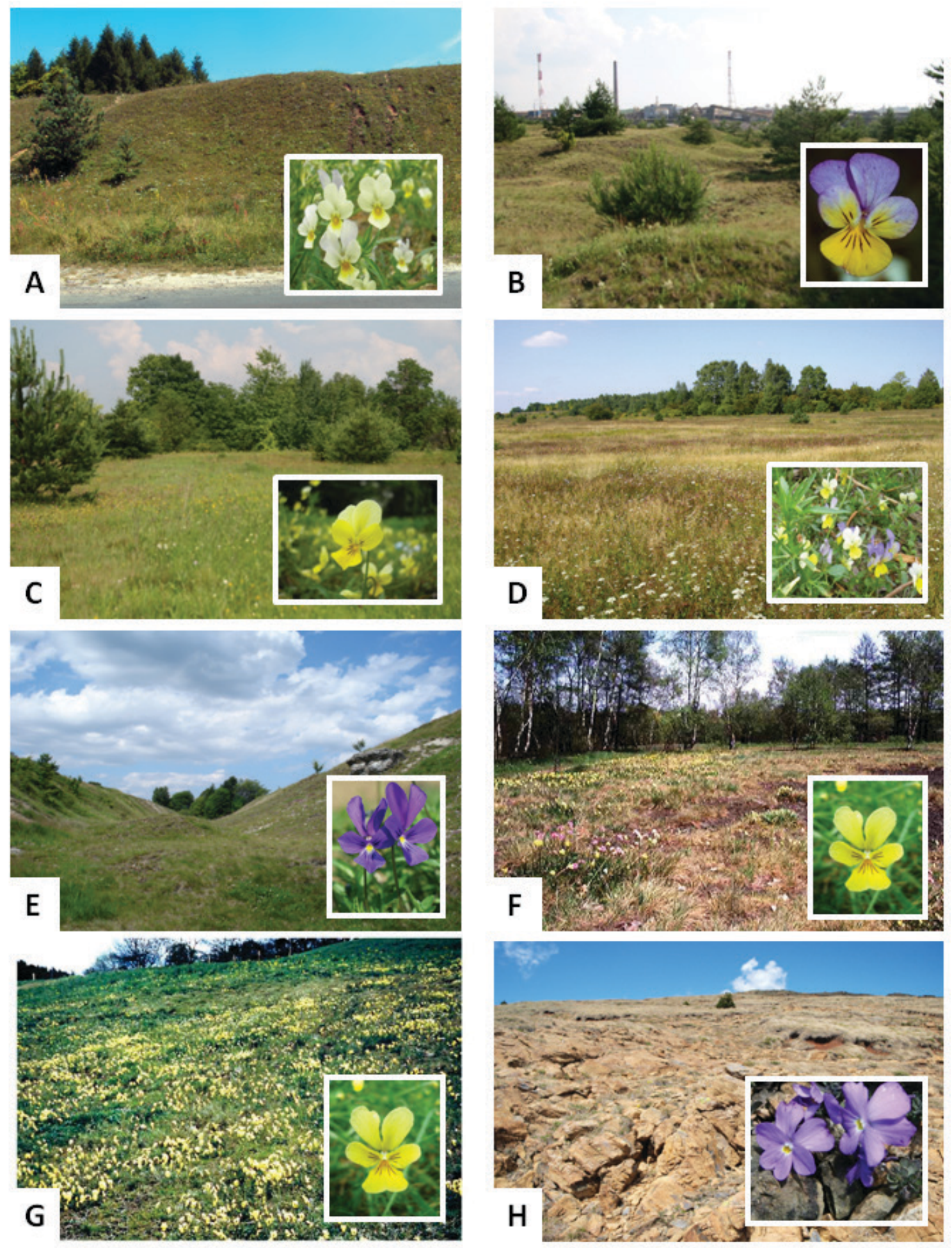

Ryc. 1. Stanowiska, na których rosna różne gatunki Viola odporne na wysokie stężenia metali ciężkich $\mathrm{w}$ glebie.

Fot. A-G gleby galmanowe bogate w cynk, ołów i kadm: A - hałda „Saturn” w Olkuszu, na której występuje fiołek trójbarwny (Viola tricolor); B-D - stanowiska V. tricolor na hałdzie w Bukownie, rozległy teren pohutniczy zróżnicowany siedliskowo; E-G - stanowiska tzw. fiołków cynkowych: E - stanowisko endemicznego niebieskiego fiołka cynkowego ( $V$. lutea ssp. westfalica) w Blankenrode, Niemcy; F-G stanowisko żółtego fiołka cynkowego (V. lutea ssp. calaminaria) w Plombières, Belgia (F) i w Breinigerberg, Niemcy (G); H - gleby serpentynowe bogate $\mathrm{w}$ nikiel, chrom, żelazo; góra Valamara w Albanii stanowisko V. albanica. Autorzy zdjęć: H. Bothe (E-G), P. Kawalec (B-D), A. Słomka (A, H). 

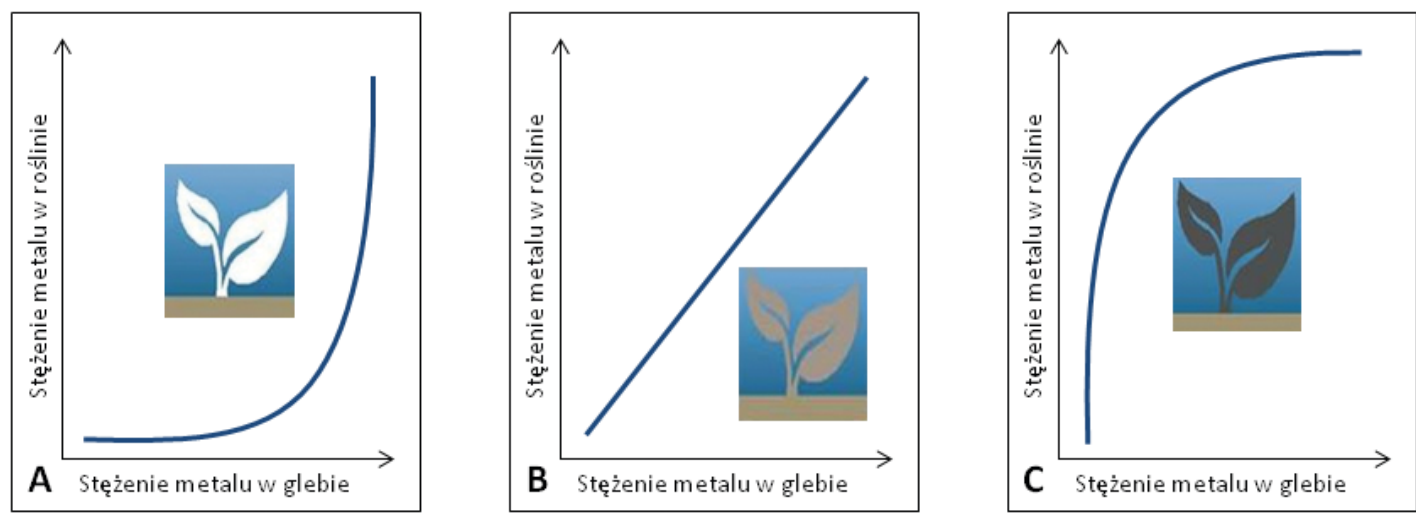

Ryc. 2. Strategie adaptacji roślin do wysokich stężeń metali ciężkich w glebie.

A - strategia wykluczania, metale głównie w korzeniach; B - strategia indykacji, stężenie metali w roślinie odpowiada stężeniu w glebie, rośliny wykorzystywane jako indykatory stopnia skażenia środowiska; C - strategia akumulacji, metale transportowane i akumulowane w częściach nadziemnych.

konstytutywna, która warunkuje podstawowy poziom tolerancji na metale. Natomiast różnice międzygatunkowe w poziomie tolerancji wynikają $z$ efektywności mechanizmów obronnych, u podstaw których leża procesy metaboliczne i molekularne. U roślin zasiedlajacych tereny o wysokich stężeniach metali ciężkich w glebie (np. na hałdach pohutniczych), występuje podwyższona tolerancja, tzw. tolerancja indukowana, wykształcona w wyniku procesów mikroewolucyjnych (WIERzBICKA 2015). Można wymienić trzy strategie obronne roślin w relacji metal-roślina: (i) wykluczania - rośliny akumuluja metale w korzeniach, nie sa one transportowane do części nadziemnych, (ii) indykacji - rośliny akumuluja w organach metale ciężkie w stężeniu, które odpowiada stężeniu metali ciężkich w glebie, dzięki czemu można na podstawie zawartości metali w suchej masie wnioskować o stopniu skażenia środowiska, w którym występują (CUMMING i TAYLOR 1990, ANTOSIEWICZ 1992, BARANOWSKA-MOREK 2003), (iii) akumulacji - rośliny akumuluja metale ciężkie w częściach nadziemnych (Ryc. 2), poprzez wytworzenie mechanizmów umożliwiających detoksykację, takich jak produkcja fitochelatyn, enzymów antyoksydacyjnych, aminokwasów, kwasów organicznych i nieorganicznych, chroniacych przed reaktywnymi formami tlenu powstającymi między innymi na skutek obecności metali w tkankach. W akumulacji metali istotnym elementem sa transportujące je białka. Ekspresja kodujacych je genów (specyficzna w różnych komórkach/tkankach/ organach), lokalizacja kodowanych białek w różnych błonach biologicznych (np. błona plazmatyczna czy tonoplast) oraz kierunek transportu jonów metali, warunkuje napływ metali do komórki i ich gromadzenie np. w wakuolach (BROOKERS i współaut. 1981, KLEIN i współaut. 2008, SŁOMKA i współaut. 2008, BOTHE 2011, EMAMVERDIAN i współaut. 2015). Wśród roślin przejawiających strategię akumulacji, występuje wyjatkowa grupa ok. 500 gatunków, tzw. hiperakumulatorów, magazynujacych metale ciężkie w częściach nadziemnych w ilości ponadprogowej, czyli według najnowszej definicji, o dwa rzędy wielkości większej niż inne gatunki rosnace w tych samych warunkach lub ich odpowiedniki (gatunki $z$ tego samego rodzaju) rosnace na glebach niezanieczyszczonych/ mniej zanieczyszczonych (RASCIO i NAVARI-IZZO 2011, KRZCIUK 2015, VAN DER ENT i współaut. 2015). Metalofity sa bardzo ważnymi składnikami flory, bowiem sa wykorzystywane do oczyszczania gleb $z$ metali ciężkich w procesie fitoremediacji (SIWEK 2008b, MAŁKOWSKI 2015).

Potwierdzenie występowania metali w organach, tkankach, a nawet pojedynczych komórkach jest zależne od czułości stosowanej metody. Na poziomie komórki i organelli komórkowych metale można wykrywać stosując różne techniki, w połączeniu $z$ mikroskopią skaningowa, elektronowa bądź protonową. Do oceny ilości metali w całych organach (biomasie roślinnej) służą techniki spektrometrii: absorpcyjna spektrometria atomowa (ang. atomic absorption spectrometry, AAS), spektrometria mas $z$ jonizacja w plazmie sprzężonej indukcyjnie (ang. inductively coupled plasma mass spectrometry, ICP-MS), spektrometria mas $z$ jonizacja $\mathrm{w}$ plazmie sprzężonej indukcyjnie $z$ analizatorem kwadrupolowym i przystawka do odparowania laserowego (ang. laser ablation inductively coupled plasma mass spectrometry, LA-ICP-MS). Bez skomplikowanych urządzeń, wykrywanie metali w tkankach można 


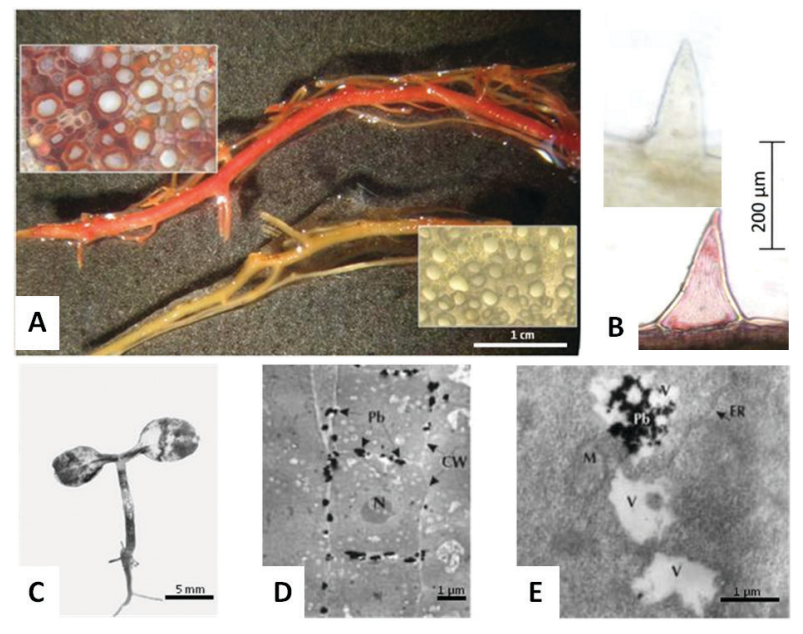

Ryc. 3. Metody wykrywania metali ciężkich w organach, tkankach i komórkach roślinnych.

A-C - histochemiczne $z$ wykorzystaniem barwników: ditizon (A, B) i rodizonian sodu (C): A - odcięte korzenie i przekroje poprzeczne przez korzenie Viola tricolor ze stanowiska kontrolnego (brak zabarwienia) i zanieczyszczonego $\mathrm{Pb}, \mathrm{Zn}, \mathrm{Cd}$ (zabarwione), fot. A. Słomka; B włoski liści $V$. tricolor ze stanowiska kontrolnego (brak zabarwienia) i zanieczyszczonego $\mathrm{Pb}, \mathrm{Zn}, \mathrm{Cd}$ (zabarwiona), fot. A. Wilk; C - siewki a Viola $\mathrm{x}$ wittrockiana zabarwione rodizonianem sodu po traktowaniu siarczanem cynku aplikowanym do gleby (zabarwione korzenie i liścienie), fot. K. Sychta; D-E - komórki korzenia Dianthus carthusianorum po traktowaniu ołowiem $z$ transmisyjnego mikroskopu elektronowego, w których widoczne są złogi ołowiu w ścianie komórkowej (D) oraz w wakuoli (E) (wg BARANOWSKA-MOREK i WIERZBICKA 2004, zmieniona).

przeprowadzić stosując związki wykazujace powinowactwo do metali, np. cynkon, ditizon, rodizonian sodu (BARANOWSKA-MOREK i WIERZBICKA 2004, SEREGIN i KOZHEVNIKOVA 2011) (Ryc. 3).

Tolerancja roślin na metale ciężkie była $i$ jest intensywnie badana $z$ wykorzystaniem, jako modeli badawczych, całych roślin w warunkach in vivo. Między innymi badano wpływ metali ciężkich na wzrost i biomase roślin, parametry biochemiczne takie jak: zawartość metabolitów wtórnych, aktywność enzymów stresu, reakcje aparatu fotosyntetycznego, procesy reprodukcyjne, wielkość genomu, liczbę chromosomów oraz akumulację metali ciężkich w tkankach roślinnych (JEDRZEJCZYK i współaut. 2002; PERFUS-BARBEOCH i współaut. 2002; SŁOMKA i współaut. 2008, 2010, 2011; JOHN i współaut. 2009; MUSZYŃSKA i współaut. 2014; IZMAIŁow i współaut. 2015; OKEM i współaut. 2015).

W Polsce południowej znajduje się Olkuski Okręg Rudny (OOR), gdzie od XII w. wydobywano i przetwarzano rudy cynku i ołowiu. Obszar ten jest doskonałym laboratorium biologicznym, bowiem można tam obserwować sukcesję roślin na hałdy o wy- sokich stężeniach tych pierwiastków oraz zachodzace tam procesy mikroewolucyjne (GRODZIŃSKA i SZAREK-ŁUKASZEWSKA 2002, WIERZBICKA 2002, WIERZBICKA i ROSTAŃSKI 2002, SZAREK-ŁUKASZEWSKA i współaut. 2015).

W ostatnich latach, w badaniach nad wpływem metali ciężkich na rośliny coraz częściej stosuje się technikę kultur in vitro, wykorzystując jako model zawiesiny komórkowe.

\section{KULTURY ZAWIESINOWE - MODEL DO BADAN REAKCJI KOMÓREK ROŚLINNYCH NA WYSOKIE STEZŻENIA METALI CIEŻ̇KICH}

Wykorzystanie kultur zawiesinowych komórek jest od niedawna stosowana technika do badań nad wpływem metali ciężkich na organizm roślinny. Pozwala na analizę odpowiedzi na stres pojedynczych komórek $\mathrm{w}$ stabilnych warunkach kultur in vitro, co zapewnia wysoka dokładność badań oraz powtarzalność wyników ze względu na kontrolowane warunki. Nie można jednak pominąć faktu, że w takim modelu badawczym odpowiedź będzie specyficzna dla pojedynczych komórek w zawiesinie, nie dla określonych typów komórek/tkanek/organów, a tym samym procesy analizowane nie będa podlegały regulacji na poziomie całej rośliny. Ponadto, w zależności od strategii obronnej jaka roślina wykształciła w toku ewolucji, komórki różnych tkanek zlokalizowanych w organach nadziemnych (łodyga, liść) lub podziemnych (korzenie, kłacza), będa akumulowały metale. Kultury zawiesinowe komórek sa zwykle wyprowadzane $z$ tkanki przyrannej (kalusowej) lub $z$ eksplantatu umieszczonego w pożywce płynnej (KIERAN i współaut. 1997) (Ryc. 4). W celu przeprowadzenia analiz wpływu metali ciężkich na procesy fizjologiczne i biologie komórki, kluczowe jest wykreślenie krzywej wzrostu kultury zawiesinowej oraz ustalenie wieku w jakim kultura osiąga odpowiednia fazę wzrostu, czyli faze wzrostu wykładniczego, podczas której zostana zaaplikowane metale (MALDONADO-MAGAÑA i współaut. 2013, BERNABÉ-ANTONIO i współaut. 2015). Krzywa wzrostu komórek jest ustalana poprzez monitorowanie liczby komórek zawiesiny, codziennie lub co kilka dni. Pomiary wzrostu liczby komórek moga być wykonywane kilkoma metodami: 1) pomiar świeżej masy komórek - ustalona objętość zawiesiny zostaje odwirowana i supernatant oddzielony lub zawiesina zostaje odsaczona na lejku Buchnera $z$ filtrem; 2) pomiar suchej masy komórek - ustalona objętość zawiesiny zostaje wysuszona w $70^{\circ} \mathrm{C}$ w piecu próż- 


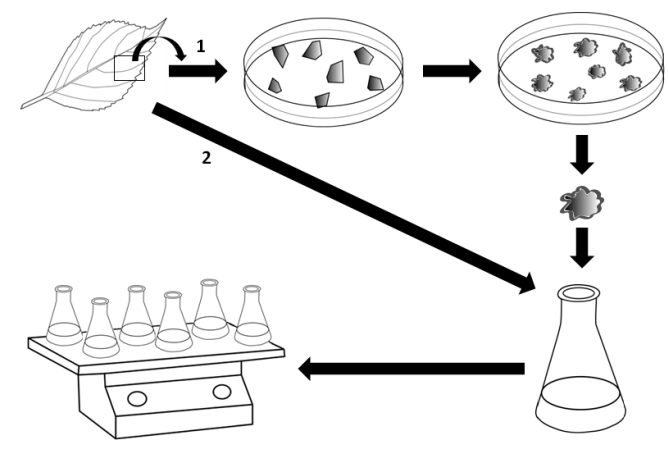

Ryc. 4. Schemat uzyskiwania kultur zawiesinowych komórek $z$ fragmentów blaszki liściowej (eksplantat) pośrednio via kalus (1) lub bezpośrednio $z$ eksplantatu (2).

niowym, a następnie zważona; 3) liczenie komórek w hemocytometrze po maceracji trójtlenkiem chromu; 4) ustalenie procentu osiadłych komórek (SCV) - zawiesina zostaje na 30 minut poza wytrzassarka, a następnie szacowany jest procent osiadłych komórek w stosunku do poziomu pożywki; 5) ustalenie procentu odwirowanych komórek (PCV) - pobierana ustalona objętość zawiesiny, odwirowana, a następnie szacowany jest procent osiadłych komórek w stosunku do danej objętości (RYU i współaut. 1990). Na podstawie krzywej wzrostu określa się czas podwojenia populacji (ang. doubling time), który zwykle wynosi od kilku godzin do kilku dni (Ryc. 5).

Zastosowanie kultur zawiesinowych komórek pozwala na lepsze zrozumienie fizjologii i biologii komórek roślinnych, w reakcji na czynnik stresowy jakim sa metale ciężkie. Do badań nad wpływem działania metali ciężkich na procesy fizjologiczne komór$\mathrm{ki}$, analizowane na poziomie molekularnym, wykorzystywano protoplasty (DoDDS 1983). Okazało się jednak, że nie jest to dobry model, ponieważ właściwości protoplastów nie odpowiadały cechom komórek roślin wyjściowych, $z$ powodu braku ściany komórkowej, która stwarza bariere dla wnikania metali ciężkich do wnętrza komórki. Protoplasty sa znacznie bardziej wrażliwe na działanie metali. Kluczowym zagadnieniem przy wyborze kultur zawiesinowych do analiz jest wykazanie, iż mechanizmy tolerancji w obu układach, komórki-roślina, sa porównywalne. Badania nad Thlaspi (=Noccaea) caerulescens udowodniły, że linie komórkowe odzwierciedlaja tolerancję na metale roślin wyjściowych (wyższe zapotrzebowanie na cynk do wzrostu, zwiększona ekspresja genów transportu metali, wysoka tolerancja na podwyższony poziom metali ciężkich), dlatego kultury zawiesinowe sa odpowiednim modelem do badań nad akumulacja metali, tolerancja

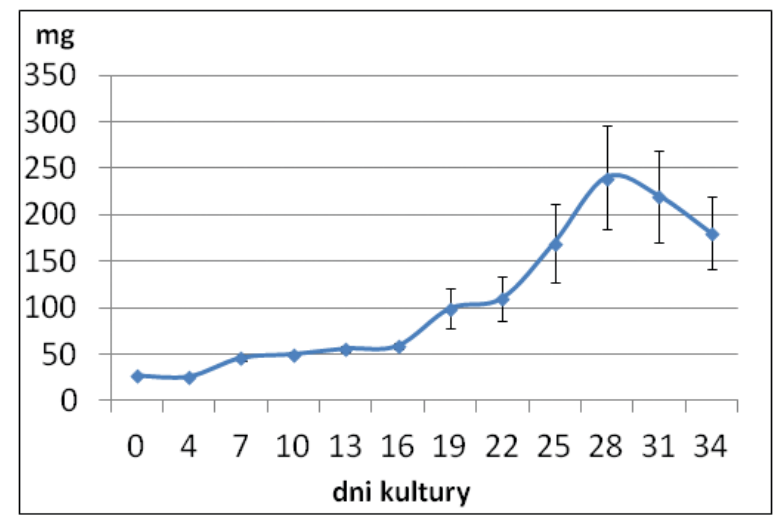

Ryc. 5. Krzywa wzrostu komórek na przykładzie kultury zawiesinowej Viola tricolor uzyskanej z kalusa. Pomiar świeżej masy komórek wykonywany co trzy dni od zainicjowania kultury, wyniki dla trzech powtórzeń hodowli.

roślin czy ekspresją genów odpowiedzialnych za transport metali. Reakcje komórek roślinnych na czynniki stresowe sa podobne jak roślin, $z$ których została wyprowadzona zawiesina. Zależność tę wykazano w badaniach fizjologicznych i molekularnych, porównując gatunki reprezentujące różny poziom tolerancji na metale ciężkie: hiperakumulatora (T. caerulesces) oraz nietolerancyjnego taksonu (Arabidopsis thaliana) (KLEIN i wspó1aut. 2008). Podobne wyniki, wskazujace na korelację tolerancji na cynk i ołów między rośliną wyjściowa a zawiesina komórkowa, wykazano u jadłoszynu górskiego (Prosopis laevigata) (BUENDÍA-GONZÁLES i współaut. 2010, MALDONADO-MAGAÑA i współaut. 2013).

Roślinne kultury zawiesinowe, szeroko stosowane w biotechnologii jako surowce do uzyskiwania wtórnych metabolitów, sa jednym $z$ najbardziej efektywnych systemów do produkcji tych zwiąków w dużej ilości i stosunkowo wysokiej czystości, w tym metabolitów wykorzystywanych do produkcji leków, dodatków do żywności (np. antocyjany, alkaniny, żółć szafranowa, szafran i inne naturalne barwniki), ze względu na łatwość ich otrzymywania, szybkość produkcji i opłacalność (MISAWA 1994, DöRNENBURG i KNORR 1997, YUE i współaut. 2016). Zastosowanie niewielkich dawek metali ciężkich w kulturach zawiesinowych może powodować zwiększenie produkcji metabolitów wtórnych przez komórki. W niskich dawkach działaja one jak elicytory, czyli zwiazki chemiczne, które indukuja biochemiczne reakcje obronne roślin (ZHAO i współaut. 2010). Wykazano, że zastosowanie chlorku kadmu w kulturach zawiesinowych winorośli właściwej, w odpowiednim stężeniu, zwiększa biosyntezę związków fenolowych oraz tokoferoli (ÇETİN i współaut. 2014), a siarczan kadmu wpływał 
pozytywnie na synteze trans-resweratrolu (polifenolowa pochodna stilbenu o działaniu antyrodnikowym występująca w dużych ilościach w czerwonym winie), zwiększając jego wytwarzanie nawet kilkakrotnie w porównaniu $z$ komórkami nietraktowanymi kadmem (ÇETİN i BAYDAR 2016). Również w kulturach zawiesinowych świerka czerwonego badano wpływ cynku i kadmu na biosynteze i poziom związków tiolowych (fitochelatyn, Y-glutamylocysteiny, glutationu), wolnych aminokwasów i poliamin, które u roślin spełniają rolę metaloprotektantów (THANGAVEL i współaut. 2007).

Kultury zawiesinowe były także wykorzystywane do badania wpływu metali ciężkich na cykl komórkowy. U Glycine max (soja warzywna) hamowanie podziałów komórkowych, w wyniku działania metalami ciężkimi, było efektem uszkodzeń DNA. Jony kadmu powoduja wcześniejsze wejście komórki w fazę S cyklu komórkowego i obniżenie tempa syntezy DNA oraz zaburzają wejście w fazę $M$, co ma negatywny wpływ na przebieg podziałów mitotycznych (SOBKOWIAK i DECKERT 2004).

\section{KOMÓRKA ROŚLINNA - MECHANIZMY POBIERANIA I OCHRONY PRZED METALAMI CIEŻKIMI}

Metale ciężkie moga wnikać do komórki roślinnej przez błonę komórkową w procesie endocytozy lub za pośrednictwem specjalnych transporterów błonowych (WOŹNY i współaut. 1982, SIWEK 2008b, KUTROWSKA 2013, VIEHWEGER 2014 i cyt. tam lit.). Obecność metali ciężkich w komórkach powoduje różnego rodzaju modyfikacje w organellach i metabolizmie komórki, poprzez produkcję reaktywnych form tlenu w wyniku stresu oksydacyjnego (RUCIŃSKA-SoBKOWIAK i PUKACKI 2006). Mechanizmy ochronne komórek roślinnych na metale ciężkie obejmuja wykluczanie - komórka jest chroniona przed wnikaniem metali ciężkich do wnętrza protoplastu, oraz mechanizmy tolerancji polegajace na neutralizowaniu toksycznego wpływu metali we wnętrzu komórki i usuwanie ich $z$ protoplastu (LEVITT 1980, HOSSAIN i współaut. 2012). Na zewnątrz protoplastu metale sa akumulowane przez grzyby mikoryzowe, gromadzone w ścianie komórkowej lub ich transport do wnętrza komórki jest blokowany przez warstwę wielocukru, kalozy (VOLLENWEIDER i współaut. 2006, MEYERS i współaut. 2009). U wielu gatunków roślin metale ciężkie są akumulowane w dużych ilościach w ścianach komórkowych, gdzie łaczą się $z$ grupami karboksylowymi (MALDONADO-MAGAÑA i współaut. 2013). W ścianie komórkowej kluczowa rolę $\mathrm{w}$ wy- chwytywaniu metali ciężkich pełnią polisacharydy. Wśród polisacharydów można wyróżnić pektyny, w strukturze których główna domeną odpowiedzialną za wychwytywanie metali dwu- i trójwartościowych jest domena HGA (homogalakturonianowa), syntetyzowana w aparacie Golgiego i transportowana w peccherzykach sekrecyjnych do ściany komórkowej (DRONNET i współaut. 1996, WILLATS i współaut. 2006). Deponowanie metali ciężkich w ścianie komórkowej można obserwować używając mikroskopii optycznej (ołów - barwienie ditizonem lub rodizonianem sodowym), fluorescencyjnej i konfokalnej (kadm - barwienie odczynnikiem Leadmium, aluminium - barwienie moryna lub lumogallionem) oraz mikroskopii transmisyjnej elektronowej (Ryc. 3D, E). Można także analizować depozycję metali w ścianie za pomoca mikroanalizy rentgenowskiej (KRZESŁOWSKA 2011). Zawartość metali ciężkich w komórkach może być oszacowana (i) pośrednio przez ustalenie różnicy w ilości metali w pożywce na początku kultury oraz po czasie trwania eksperymentu lub (ii) bezpośrednio poprzez oznaczenie zawartości metalu w biomasie komórkowej metoda absorpcyjnej spektrometrii atomowej i modyfikacjami tej metody (ZHU i CULLEN 1995, KLEIN i współaut. 2008). W cytoplazmie metale sa chelatowane przez fitochelatyny, kwasy organiczne $\mathrm{i}$ następnie deponowane w wakuoli (VOLLENWEIDER i współaut. 2006).

\section{TESTY ŻYWOTNOŚCI KOMÓREK - BADANIE TOLERANCJI NA METALE CIEŻZKIE}

Kluczowym w badaniu tolerancji na metale ciężkie komórek jest oznaczenie ich żywotności przed, w trakcie i po zastosowaniu czynnika stresowego. W przypadku szacowania żywotności komórek w kulturze po zastosowaniu czynnika stresowego oznacza się minimalne stężenie hamujące (ang. minimum inhibitory concentration, MIC) lub minimalne stężenie śmiertelne (ang. minimum lethal concentration, MLC). W toksykologii, w badaniach nad zwierzętami, używa się oznaczenia $\mathrm{LC}_{50}$ (ang. lethal concentration), co oznacza, że przy danej dawce 50\% osobników nie przeżyło ekserymentu. W przypadku roślin można zastosować parametr $\mathrm{IC}_{50}$ (ang. inhibitory concentration), określajacy stężenie hamujące, które powoduje redukcję biomasy komórkowej o 50\% (ZHU i CULLEN 1995).

Żywotność komórek w kulturze zawiesinowej można także, poza pomiarami biomasy, oznaczać za pomocą testów $z$ użyciem barwników przyżyciowych lub uwidaczniajacych martwe komórki. Martwe 


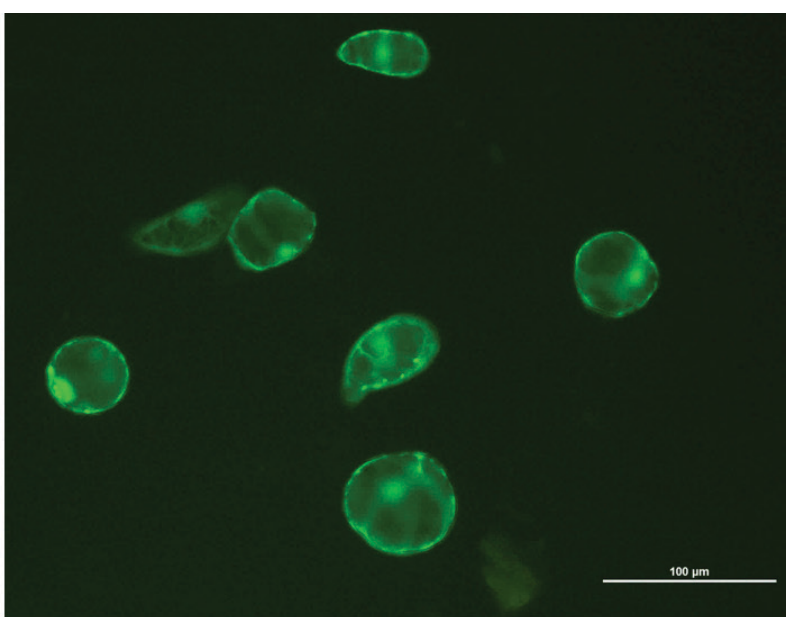

Ryc. 6. Komórki kultury zawiesinowej Viola tricolor wyprowadzonej $\mathrm{z}$ kalusa zabarwione dwuoctanem fluoresceiny (FDA) - żywe komórki wykazuja fluorescencję w mikroskopie fluorescencyjnym (fot. K. Sychta).

komórki identyfikowane sa za pomoca błękitu Evansa, błękitu bromofenolowego, błękitu metylenowego oraz fenosafraniny. Błękit Evansa i błękit metylenowy sa redukowane przez żywe komórki, co skutkuje utrata barwy, w martwych komórkach barwniki te pozostaja niezmienione. Do oznaczenia żywotności stosowane sa także barwniki tetrazolowe, wybarwiajace żywe komórki, takie jak MTT [bromek 3-(4,5-dimetylotiazol-2-ilo)-2,5-difenylotetrazoliowy] oraz TTC (chlorek trójfenylotetrazoliowy). Sole tetrazolowe sa redukowane w żywych komórkach do czerwono zabarwionych formazanów przez enzymy - dehydrogenazy (TISSERAT i MANTHEY 1996, VERSLEYEN i współaut. 2004).

Żywotność komórek w testach $z$ użyciem czynników stresowych najczęściej jest jednak ustalana na podstawie barwienia podwójnego FDA (dwuoctan fluoresceiny) oraz PI (jodek propidyny), z użyciem mikroskopu fluorescencyjnego. Żywe komórki są uwidaczniane za pomoca dwuoctanu fluoresceiny, który jest rozkładany przez enzym esteraze, dając produkt fluoryzujący (FERNANDEZ-DA SILVA i MEnÉndeZ-Yuffá 2006) (Ryc. 6). Jodek propidyny jest barwnikiem barwiacym kwasy nukleinowe, przenika przez uszkodzone błony komórkowe i łaczy się z DNA; komórki zabarwione sa martwe (PoBORILOVA i współaut. 2013).

Od niedawna w badaniach żywotności komórek w kulturach zawiesinowych roślin stosuje się test alamarBlue, powszechnie wykorzystywany do oceny żywotności w kulturach komórek zwierzęcych. Żywe komórki emitują różową fluorescencję, bowiem w wyniku procesów metabolicznych komórki, niebieska resazuryna jest redukowana do resorufiny o różowej fluorescencji. Pomiarów ilości otrzymanego produktu można dokonać spektrofotometrycznie lub fluorymetrycznie (BYTH i współaut. 2001, RAMPERSAD 2012).

Badanie żywotności komórek w kulturach zawiesinowych traktowanych metalami jest kluczowe do oceny wpływu metali ciężkich na przeżycie oraz określenia tolerancji danej linii komórkowej na aplikowane metale.

\section{ŚMIERĆ KOMÓREK W REAKCJI NA METALE CIEŻKIE - PROGRAMOWANA SMIERC KOMORKI CZY NEKROZA?}

Kultury zawiesinowe komórek roślinnych sa także bardzo dobrym materiałem do badań nad programowana śmiercia komórek (ang. programmed cell death, PCD) pod wpływem różnych czynników biotycznych i abiotycznych (MCCABE i LEAVER 2000). Ostatnio, programowana śmierć komórek u roślin została rozdzielona na dwa typy: rozwojowa (ang. developmental programmed cell death, dPCD), uczestniczącą w procesie różnicowania komórek i specjalizacji tkanek do pełnienia określonych funkcji, oraz środowiskowa (ang. environmental programmed cell death, ePCD), będacą odpowiedzią rośliny/ komórek na stres środowiskowy (LAM 2004, OLVERA-CARILLO i współaut. 2015).

$\mathrm{Na}$ skutek działania czynników abiotycznych (np. UV, wysoka temperatura, sól), w tym również metali ciężkich, komórki roślinne ulegaja PCD poprzez transdukcję sygnału, wywołana przez reaktywne formy tlenu (ang. reactive oxygen species, ROS) prowadzace do ekspresji genów zwiazanych z PCD (PETROV i współaut. 2015 i cyt. tam lit.), ale moga również ulegać nekrozie (YAKIMOVA i współaut. 2006, HELMERSSON i współaut. 2008, DE MiCHELE i współaut. 2009, VAN DOORN i współaut. 2011, XU i współaut. 2013, HUANG i współaut. 2014). Istnieje kilka wskaźników biochemicznych pozwalajacych na rozróżnienie nekrozy od PCD (VAN DOORN i współaut. 2011). Komórki podlegajace PCD można wykryć za pomoca kilku testów, między innymi testem kometowym (CHARZYŃSKA i współaut. 2000) lub testem TUNEL (WIERZCHOWIECKA i współaut. 2008, El-MAAROUF-BOUTEAU i współaut. 2011), z jednoczesnym barwieniem jodkiem propidyny (PI). Test TUNEL pozwala na wyodrębnienie komórek, których jądro komórkowe ulega fragmentacji (zarówno w komórkach nekrotycznych, jak i podlegajacych PCD). Komórki nekrotyczne charakteryzuja się brakiem integralności błony komórkowej. Jodek propidyny wybarwia komórki, które mają uszkodzoną błonę komórkową. Połączenie tych dwóch metod pozwala na wyodrębnienie komórek ulegajacych nekrozie (TUNEL - pozytywne i PI - pozytywne) oraz komórek 
ulegajacych PCD (TUNEL - pozytywne i PI - negatywne) (ÜNAL-CEVIK i współaut. 2004). Stosunkowo niedawno odkryto, że kaspazy, enzymy $z$ grupy proteaz, biorace udział $\mathrm{w}$ PCD komórek zwierzęcych, uczestnicza także w PCD komórek roślinnych (LAM i DEL POZO 2000). Ustalenie poziomu aktywacji kaspaz w komórkach pozwala oszacować częstotliwość zachodzenia PCD po traktowaniu czynnikiem stresowym, np. metalami ciężkimi (YAKIMOVA i współaut. 2007, YE i współaut. 2013). W przeprowadzonym doświadczeniu nad wpływem jonów $\mathrm{Al}^{3+}$ na żywotność komórek tytoniu $\mathrm{w}$ kulturze zawiesinowej, udział PCD w śmierci komórek ustalono wykorzystując test TUNEL oraz badając aktywność kaspazy 3 (PoBorilova i współaut. 2013). Aktywność kaspazy 3 u roślin jest łączona ze stresem oksydacyjnym i programowana śmiercia komórki (ZHANG i współaut. 2009). Podobne właściwości do kaspaz (inicjacja szlaku PCD), wykazują enzymy znajdujące się w wakuolach roślinnych (ang. vacuolar processing enzymes, VPEs). Ich wysoka aktywność jest skorelowana ze śmiercią komórki, natomiast niska zapobiega śmierci komórek, co sugeruje, że odgrywaja one rolę w PCD. Enzymy wakuolarne posiadaja bardzo duże podobieństwo strukturalne i funkcjonalne do kaspazy 1 (Hatsugai i wspólaut. 2015).

\section{KULTURY ZAWIESINOWE KOMÓREK VIOLA A TOLERANCJA NA CYNK I OEÓW}

Taksony z rodzaju Viola (fiołek) są często wykorzystywane do badań nad tolerancja roślin na metale ciężkie, ze względu na duża liczbę gatunków występujących na glebach metalonośnych. Wyprowadzenie zawiesin komórkowych taksonów charakteryzujacych sie różnym poziomem tolerancji na obecność wysokich stężeń metali ciężkich w glebie (metalofity obligatoryjne, fakultatywne, przygodne, niemetalofity), ustalonej na podstawie frekwencji występowania osobników na różnych typach gleb (metalonośne versus niemetalonośne), pozwoli ustalić: (i) korelację pomiędzy poziomem tolerancji roślin a pochodzacych $z$ nich komórek, (ii) zdolność komórek roślin uznawanych za nietolerancyjne (niemetalofity) do uruchomienia mechanizmów obronnych pod wplywem bezpośredniego stresu i przeżycia $\mathrm{w}$ ekstremalnych warunkach, (iii) określić typ tolerancji na metale ciężkie (MicHNO 2016; Michno i współaut. 2016a, b, 2017).

\section{PODSUMOWANIE}

Kultury zawiesinowe komórek, odzwierciedlajac wiele cech fizjologicznych i biologicznych całej rośliny, jednocześnie będąc układem o stabilnych warunkach, pozwalaja na kontrolowane przeprowadzanie badań toksycznego wpływu metali ciężkich na organizmy roślinne. Kultury komórkowe sa dobrym modelem do badań na poziomie molekularnym, obejmującym ekspresję genów odpowiedzialnych za tolerancje na metale ciężkie, szlaki programowanej śmierci komórkowej, badź produkcję specyficznych białek i metabolitów wtórnych $\mathrm{w}$ odpowiedzi na stres.

\section{Streszczenie}

Zanieczyszczenia gleby metalami ciężkimi mają toksyczne działanie na rośliny, zwierzęta oraz człowieka. Metalofity, rośliny odporne na metale ciężkie, kolonizujące tereny metalonośne, sa wykorzystywane do fitoremediacji, czyli oczyszczania gleb z metali ciężkich.

Wykorzystanie roślinnych kultur komórkowych do badań nad toksycznościa metali i tolerancją komórek na ich działanie jest stosunkowo nowa technika. W pracy zostały przedstawione możliwości wykorzystania roślinnych kultur zawiesinowych w badaniach nad wpływem metali ciężkich na metabolizm komórek oraz metody oszacowania ich toksycznego wpływu. Zaprezentowane zostały techniki otrzymywania kultur zawiesinowych, oceny żywotności komórek, akumulacji metali ciężkich w komórkach. W ocenie toksyczności metali stosuje się także badania nad programowana śmiercia komórki (PCD), co pozwala oszacować reakcję komórek na ich wysokie stężenia. Zostały przedyskutowane mechanizmy tolerancji komórek na metale ciężkie. Kultury zawiesinowe sa dobrym modelem do badań tolerancji na metale, ponieważ pozwalaja zbadać ich wpływ na pojedyncze komórki w jednolitych, stałych warunkach.

\section{LITERATURA}

AgBogidi O. M., MARIERE A. E., OHWO O. A., 2013. Metal concentration in plant tissues of Jatropha curcas L. grown in crude oil contaminated soil. Int. J. Sustain. Future Human Secur. 32, 404-411.

ANTOSIEWICZ D. M., 1992. Adaptation of plants to an environment polluted with heavy metals. Acta Soc. Botan. Pol. 61, 281-299.

BARANOWSKA-MOREK A., 2003. Roślinne mechanizmy tolerancji na toksyczne działanie metali ciężkich. Kosmos 52, 283-298.

BARANOWSKA-MOREK A., WIERZBICKA M., 2004. Localization of lead in root tip of Dianthus carthusianorum. Acta Biol. Cracov. Ser. Botan. 46, 45-56.

BERNABÉ-ANTONIO A., Alvarez L., BUENDÍA-GONZÁlES L., MALDONADO-MAGAÑA A., CRUZ-SOSA F., 2015. Accumulation and tolerance of $\mathrm{Cr}$ and $\mathrm{Pb}$ using a cell suspension culture system of Jatropha curcas. Plant Cell Tissue Organ Cult. 120, 221-228.

Bотне H., 2011. Plants in heavy metal soils. [W:] Detoxification of heavy metals, soil biology 30. SHERAMETI I., VARMA A. (red.). Springer-Verlag, Berlin Heidelberg, doi: 10.1007/978-3-64221408-0 2.

BroOkers A., Collins J. C., Thurman D. A., 1981. The mechanism of zinc tolerance in grasses. J. Plant Nutrit. 3, 695-705.

BUENDÍA-GONZÁleS L., OROZCO-VILlAFUERTE J., EstradA-ZÚÑiga M. E., BARrera DíaZ C. E., VERNON-CARTER E. J., CRUZ-SOSA F., 2010. In 
vitro lead and nickel accumulation in mesquite (Prosopis laevigata) seedlings. Rev. Met. Ing. Quím. 9, 1-9.

Byth H. A., MChunu B. I., Dubery I. A., BORNMAN L., 2001. Assessment of a simple, non-toxic alamar blue cell survival assay to monitor tomato cell viability. Phytochem. Anal. 12, 340346.

CegieŁKowska W., MichalsKa-Kocymirow M. WIERZBICKA M., 2015. Metale ciężkie $w$ środowisku. [W:] Ekotoksykologia - rośliny, gleby, metale. WIERZBICKA M. (red.). Wydawnictwo Uniwersytetu Warszawskiego, Warszawa, 2351.

CETİN E. S., GÖKTÜRK-BAYDAR N., 2016. Elicitor applications to cell suspension culture for production of phenolic compounds in grapevine. Tarim Bilimleri Dergisi 22, 42-53.

ÇETÍN E. S., BABALIK Z., HALlaC-TÜRK F., GÖKTÜRK-BAYDAR N., 2014. The effects of cadmium chloride on secondary metabolite production in Vitis vinifera $c v$. cell suspension cultures. Biol. Res. 47, 47-52.

Charzyńska M., Simeonova E., Sikora A., MoSTOWSKA A., LEŚNIEWSKA J., 2000. Application of the comet assay in studies of Programmed Cell Death (PCD) in plants. Acta Soc. Botan. Pol. 69, 101-107.

Cumming J. R., TAYLOR G. J., 1990. Mechanisms of metal tolerance in plants: Physiological adaptations for exclusion of metal ions from the cytoplasm. [W:] Stress responses in plants: adaptation and acclimation mechanisms. Alscher R. G., CUMMING J. R. (red.). Wiley-Liss. Inc, 329-359.

De Michele R., Vurro E., Rigo C., Costa A., Elviri L., Di VAlentin M., CARERI M., ZOTTINI M., SANITA DI TOPPI L., LO SCHIAVO F., 2009. Nitric oxide is involved in cadmium-induced Programmed Cell Death in Arabidopsis suspension culture. Plant Physiol. 150, 217-228.

DoDDS J. H., 1983. The use of protoplast technology in tissue culture of trees. [W:] Tissue culture of trees. DoDDS J. H. (red.). Boston, $\mathrm{Ma}, 103-112$.

DöRNENBURG H., KNORR D., 1997. Challenges and opportunities for metabolite production from plant cell and tissue culture. Food Technol. $51,47-53$.

Dronnet V. M., Renard C. M. G. C., Axelos M. A. V., ThiBAUlT J. F., 1996. Heavy metals winding by pectins: selectivity, quantification and characterization. Carbohyd. Polym. 30, 253-263

El-MaAROUF-Bouteau H., Mazuy C., Corbineau F., BAILlY C., 2011. DNA alteration and programmed cell death during ageing of sunflower seed. J. Exp. Bot. 62, 5003-5011.

EMAMVERDIAN A., Ding Y., MOKHBERDORAN F., XIE Y., 2015. Heavy metal stress and some mechanisms of plant defense response. Scient. World J., doi: 10.1155/2015/756120.

FERNANDEZ-DA Silva R., MENENDEZ-Yuffá A., 2006. Viability in protoplasts and cell suspension of Coffea arabica cv. Catimor. Electr. J. Biotechnol., doi: 10.2225/vol9-issue5-fulltext-4.

GRODZIŃSKA K., SZAREK-ŁUKASZEWSKA G., 2002. Hałdy cynkowo-ołowiowe $w$ okolicach Olkusza - przeszłość, teraźniejszość i przyszłość. Kosmos 51, 127-138.

HATSUGAI N., YAMADA K., GOTO-YAMADA S., HARA-NISHIMURA I., 2015. Vacuolar processing enzyme in plant programmed cell death. Front. Plant Sci., doi: 10.3389/fpls.2015.00234.
HELmersson A., VON ARNOLD S., BOzHKov P. V., 2008. The level of free intracellular zinc mediates Programmed Cell Death/cell survival decisions in plant embryos. Plant Physiol. 147, 1158-1167.

Hossain M. A., Piyatida P., Teixeira de Silva J. A., FUJITA M., 2012. Molecular mechanism of heavy metal toxicity and tolerance in plants: central role of glutathione in detoxification of reactive oxygen species and methylglyoxal and in heavy metal chelation. J. Botan., doi: 10.1155/2012/872875.

Huang W., Yang X., YaO S., LwinOo T., He H., WANG A., LI C., HE L., 2014. Reactive oxygen species burst induced by aluminum stress triggers mitochondria-dependent programmed cell death in peanut root tip cells. Plant Physiol. Biochem. 82, 76-84.

IZMAIEOW R., KOŚCIŃSKA-PAJAK M., KWIATKOWSKA M., Musiat M., 2015. Wptyw metali cięzkich na procesy reprodukcyjne roślin. [W:] Ekotoksykologia. Rośliny, gleby, metale. WIERzBICKA M. (red.). Wydawnictwo Uniwersytetu Warszawskiego, Warszawa, 96-114.

JEDRZEJCZYK M., ROSTAŃSKI A., MAŁKOWSKI E., 2002. Accumulation of zinc and lead in selected taxa of the genus Viola L. Acta Biol. Cracov. Ser. Botan. 44, 49-55.

John R., Ahmad P., Gadgil K., Sharma S., 2009. Heavy metal toxicity: Effect of plant growth, biochemical parameters and metal accumulation by Brassica juncea L.. Int. J. Plant Product. 3, 65-76.

Kieran P. M., Macloughlin P. F., Malone D. M., 1997. Plant cell suspension cultures: some engineering considerations. J. Biotechnol. 59, 39-52.

Klein M. A., Sekimoto H., Milner M. J., Kochian L. V., 2008. Investigation of heavy metal hyperaccumulation at the cellular level: Development and characterization of Thlaspi caerulescens suspension cell lines. Plant Physiol. 147, 2006-2016.

KRZCIUK K., 2015. Hiperakumulatory roślinne charakterystyka, badania $i$ znaczenie praktyczne. Kosmos 64, 293-304.

KRZESŁOWSKA M., 2011. The cell wall in plant cell response to trace metals: polysaccharide remodeling and its role in defense strategy. Acta Physiol. Plant. 33, 35-51.

KUTROWSKA A., 2013. Roślinne transportery błonowe metali śladowych. Kosmos 62, 105-113.

LAM E., 2004. Controlled cell death, plant survival and development. Nat. Rev. Mol. Cell Biol. 5, 305-315.

LAM E., DEL POZO O., 2000. Caspase-like protease involvement in the control of plant cell death. Plant Mol. Biol. 44, 417-428.

LEVITT J., 1980. Response of plants to environmental stresses. Academic Press, New York.

MaldonAdo-Magaña A., OROZCO-VIllafuerte J., Buendia-GonZales L., Estrada-Zuniga M. E., BERNABÉ-ANTONIO A., CRUZ-SOSA F., 2013. Establishment of cell suspension cultures of Prosopis laevigata (Humb. \& Bonpl. Ex Willd) M.C. Johnst to determine the effect of zinc on uptake and accumulation of lead. Rev. Met. Ing. Quím. 12, 489-498.

MAŁKOWSKI E., 2015. Fitoremediacja metali ciézkich. [W:] Ekotoksykologia. Rośliny, gleby, metale. WIERZBICKA M. (red.). Wydawnictwo Uniwersytetu Warszawskiego, Warszawa, 469506.

MCCABE P. F., LEAVER C. J., 2000. Programmed cell death in cell cultures. Plant Mol. Biol. 44, 359-368. 
Meyers D. E., KopitTKe P. M., Auchterlonie G. J., WEBB R. I., 2009. Characterization of lead precipitate following uptake by roots of Brassica juncea. Environ. Tox. Chem. 28, 250-255.

MichNo K., 2016. Obtaining stable cell suspension culture of Viola tricolor L. (Violaceae) to evaluate the impact of zinc and lead on cell survival. Book of abstracts of II International Student Conference of Cell Biology, 42.

Michno K., SŁomKa A., Kuta E. 2016a. Kultury zawiesinowe komórek Viola tricolor (Viola, Violaceae) jako model do badania tolerancji na wysokie stężenia metali ciężkich. [W:] Książka abstraktów. 57 Zjazd Polskiego Towarzystwa Botanicznego: Botanika - tradycja $i$ nowoczesność. SZCZUKA E., SZYMCZAK G., ŚMIGAEA M., MARCINIEC R. (red.). Polskie Towarzystwo Botaniczne, 187-188.

Michno K., SzKLARZEWicz J., DRwal E., SŁomka A., KUTA E., 2016b. Wpływ warunków kultury na żywotność komórek roślinnych $w$ kulturze zawiesinowej po aplikacji soli ołowiu. [W:] X Conference in vitro cultures in plant physiology. Acta Biol. Cracov. Ser. Botan. 58, 25.

Michno K., ŚlazaK B., Göransson U., SŁomKa A., KuTA E., 2017. Do cyclotides, cystine-rich cyclic peptides, play a role in heavy metal tolerance in facultative metallophyte Viola tricolor L.?. Book of abstracts of III International Students Conference of Cell Biology, 68.

MisaWA M., 1994. Plant tissue culture: an alternative for production of useful metabolites. FAO Agricult. Serv. Bull. 108, 89.

MUSZYŃSKA E., KatuŻNY K., HaNus-FAJERSKA E. 2014. Phenolic compounds in Hippophaë rhamnoides leaves collected from heavy metals contaminated sites. [W:] Plants in urban areas and landscape. Slovak University of Agriculture in Nitra, Faculty of Horticulture and Landscape Engineering, 11-14.

OKem A., SOUTHWAY C., STIRK W. A., STREeT R. A., Finnie J. F., VAN Staden J., 2015. Effect of cadmium and aluminum on growth, metabolite content and biological activity in Drimia elata (Jacq.) Hyacinthaceae. South Afr. J. Bot. 98, 142-147.

Olvera-CARILlO Y., VAN Bel M., VAN HaUtegem T., FEndRYCH M., HuYsmans M., Simaskova M., VAN DURME M., BUSCAIll P., RIVAS S., Coll N. S., Coppens F., MAere S., Nowack M. K., 2015. A conserved core of Programmed Cell Death indicator genes discriminates developmentally and environmentally induced Programmed Cell Death in plants. Plant Physiol. 169, 2684-2699.

PadmaVathiamma P. K., Li L. Y., 2007. Phytoremediation technology: Hyper-accumulation metals in plants. Water Air Soil Pollut. 184, 105126.

Petrov V., Hille J., Mueller-Roeber B., Gechev T. S., 2015. ROS-mediated abiotic stress-induced programmed cell death in plants. Front. Plant Sci. 6, 69-84.

Perfus-BARBEOCH L., LEONHARDT N., VAVASSEUR A., FORESTIER C., 2002. Heavy metal toxicity: cadmium permeates through calcium channels and disturbs the plant water status. Plant J. $32,539-548$.

PoBORILOVA Z., OPATRILOVA R., BABULA P., 2013. Toxicity of aluminium oxide nanoparticles demonstrated using a BY-2 plant cell suspension culture model. Environ. Exp. Bot. 91, $1-11$.

RAMPERSAD S. N., 2012. Multiple applications of Alamar Blue as an indicator of metabolic func- tion and cellular health in cell viability bioassays. Sensors 12, 12347-12360.

RASCIO N., NAVARI-IZZO F., 2011. Heavy metal hyperaccumulating plants: how and why do they do it? And what makes them so interesting? Plant Sci. 180, 169-181.

RosTAŃSKI A., NOWAK T., JĘDRZEJCZYK-KORYCIŃSKA M. 2015. Metalolubne gatunki roślin naczyniowych we florze Polski. [W:] Ekotoksykologia - rośliny, gleby, metale. WIERZBICKA M. (red.). Wydawnictwo Uniwersytetu Warszawskiego, Warszawa, 299-322.

RUCIŃSKA-SOBKOWIAK R., PUKACKI S., 2006. Antioxidative defence system in lupin roots exposed to increasing concentrations of lead. Acta Physiol. Plant. 28, 357-364.

RYU D. D. Y., LEE S. O., ROMANI R. J., 1990. Determination of growth rate for plant cell cultures: Comparative studies. Biotechnol. Bioengine. 35, 305-311.

Seregin I. V., KozHeVnikova A. D., 2011. Histochemical methods for detection of heavy metals and strontium in the tissues of higher plants. Russ. J. Plant Physiol. 58, 721-727.

SiwEK M., 2008a. Rośliny $w$ skażonym metalami ciężkimi środowisku poprzemysłowym. Czesść I. Pobieranie, transport $i$ toksyczność metali ciężkich (śladowych). Wiad. Bot. 52, 7-22.

SiWEK M., 2008b. Rośliny $w$ skażonym metalami ciężkimi środowisku poprzemysłowym. Część II. Mechanizmy detoksyfikacji $i$ strategie przystosowania roślin do wysokich stężeń metali ciężkich. Wiad. Bot. 52, 7-23.

SŁOMKA A., KUTA E., 2015. Fiołek trójbarwny Viola tricolor L.. [W:] Ekotoksykologia - rośliny, gleby, metale. WIERZBICKA M. (red.). Wydawnictwo Uniwersytetu Warszawskiego, Warszawa, 302-410.

SŁomKA A., LIBIK-KONIECZNy M., KUTA E., MisZaLSKI Z., 2008. Metallifierous and non-metalliferous populations of Viola tricolor represent similar mode of antioxidative response. J. Plant Physiol. 165, 1610-1619.

SŁomkA A., KaWAleC M., Kellner K., JęDrZeJCZYK-KORYCIŃSKA M., ROSTAŃSKI A., KUTA E., 2010. Was reduced pollen viability in Viola tricolor $L$. the result of heavy metal pollution or rather the test applied?. Acta Biol. Cracov. Ser. Bot. 52, 123-127.

SŁoMKA A., SLIWIŃSKA D., WolnY E., KELLNER K., KUTA E., 2011. Influence of heavy-metal-polluted environment on Viola tricolor genome size and chromosome number. Acta Biol. Cracov. Ser. Botan. 53, 7-15.

SŁOMKA A., GODZIK B., SZAREK-ŁUKASZEWSKA G., SHuKA L., HoEF-Emden K., BOTHE H., 2015. Albanian violets of the section Melanium, their morphological variability, genetic similarity and their adaptations to serpentine or chalk soils. J. Plant Physiol. 174, 110-123.

SOBKOWIAK R., DECKERT J., 2004. The effect of cadmium on cell cycle control in suspension culture cells of soybean. Acta Physiol. Plant. 26, 335-344.

Stevanović V., TAN K., IATRou G., 2003. Distribution of the endemic Balkan flora on serpentine I. - obligate serpentine endemics. Plant Syst. Evol. 242, 149-170.

STEVANOVIĆ B., DRAŽIĆ G., TOMOVIĆ G., ŠINŽARSEKUlić J., MElovski LJ., NOVOVIĆ I., MARKOVIĆ D. M., 2010. Accumulation of arsenic and heavy metals in some Viola species from an abandoned mine, Alchar, Republic of Macedonia (FYROM). Plant Biosyst. 144, doi: 10.1080/11263504.2010.492597. 
SZAREK-ŁUKASZEWSKA G., KAPUSTA P., GRODZIŃSKA K., 2015. Roślinność galmanowa. [W:] Ekotoksykologia - rośliny, gleby, metale. WIERzBICKA M. (red.). Wydawnictwo Uniwersytetu Warszawskiego, Warszawa, 323-334.

SZAREK-ŁUKASZEWSKA G., NOWAK T., GRODZIŃSKA K., KAPUSTA P., GODZIK B., 2015. Przyroda Olkuskiego Okręgu Rudnego. [W:] Ekotoksykologia - rośliny, gleby, metale. WIERzBICKA M. (red.). Wydawnictwo Uniwersytetu Warszawskiego, Warszawa, 163-175.

ThangaVel P., LONG S., MinOCHA R., 2007. Changes in phytochelatins and their biosynthetic intermediates in red spruce (Picea abies Sarg.) cell suspension cultures under cadmium and zinc stress. Plant Cell Tissue Organ Cult. 88, 201-216.

TISSERAT B., MANTHEY J. A., 1996. In vitro sterile hydroponic culture to study iron chlorosis. J. Plant Nutr. 19, 129-143.

ÜNAL-CEVIK I., KILINC M., CAN A., GÜRSOY-ÖZDEMIR Y., DALKARA T., 2004. Apoptotic and necrotic death mechanisms are concomitantly activated in the same cell after cerebral ischemia. Stroke, doi: 10.1161/01. STR.0000136149.81831.c5.

VAN DER ENT A., BAKER A. J. M., REeVES R. D., POllaRD A. J., SCHAT H., 2015. Commentary: Toward a more physiologically and evolutionarily relevant definition of metal hyperaccumulation in plants. Front. Plant Sci. 6, 554-556.

VAN DOORN W. G., BEERS E. P., DANGL J. L., FrankLIN-TONG V. E., Gallois P., HARA-NISHIMURA I., JONES A. M., KAWAI-YAMADA M., Lam E., Mundy J., Mur L. A., Petersen M., SMERTENKO A., TALIANSKY M., VAN BREUSEGeM F., WOlpert T., WOltering E., ZHIVOTOVSKY B., BOZHKOV P. V., 2011. Morphological classification of plant cell deaths. Cell Death Differ. 18, 1241-1246.

Versleyen H., Samyn G., VAn Bockstaele E., DeBERGH P., 2004. Evaluation of analytical techniques to predict viability after cryopreservation. Plan Cell Tissue Organ Cult. 77, 11-21.

VIEHWEGER K., 2014. How plants cope with heavy metals. Bot. Studies 55, 35-46.

VOllENWEIDER P., COSIO C., GÜNTHARDT-GOERG M. S., Keller C., 2006. Localization and effects of cadmium in leaves of a cadmium-tolerant willow (Salix viminalis L.). Part II. Microlocalization and cellular effects of cadmium. Environ. Exp. Bot. 58, 25-40.

WIERZBICKA M., 2002. Przystosowania roślin do wzrostu na hałdach ołowiowo-cynkowych okolic Olkusza. Kosmos 51, 139-150.

WIERZBICKA M., 2015. Obrona roślin przed metalami ciężkimi. [W:] Ekotoksykologia - rośliny, gleby, metale. WIERZBICKA M. (red.). Wydawnictwo Uniwersytetu Warszawskiego, Warszawa, 83-95.

WierZBICKA M., Rostański A., 2002. Microevolutionary changes in ecotypes of calamine waste heap vegetation near Olkusz, Poland: A Review. Acta Biol. Cracov. Ser. Bot. 44, 7-19.

WIERZCHOWIECKA M., SAMARDAKIEWICZ S., WOŻNY A., 2008. Programowana śmierć komórki roślinnej - proces o "wielu twarzach", Kosmos 57, 43-52.

Willats W. G. T., Knox J. P., Mikkelsen J. D., 2006. Pectin: new insights into an old polymer are starting to gel. Trends Food Sci. Technol. 17, 97-104.

WoŹNY A., ZATORskA B., MŁodZianowski F., 1982. Influence of $\mathrm{Pb}$ on the development of lupin seedlings and ultrastructural localization of this metal in the roots. Acta Soc. Botan. Pol. 5, 345-351.

Wuana R. A., OKIEIMEN F. E., 2011. Heavy metals in contaminated soils: a review of sources, chemistry, risks and best available strategies for remediation. ISRN Ecology, doi. org/10.5402/2011/402647.

Xu H., Xu W., Xi H., Ma W., He Z., Ma M., 2013. The ER luminal binding protein (BiP) alleviates $\mathrm{Cd}\left(^{+}\right)$-induced programmed cell death through endoplasmic reticulum stress-cell death signaling pathway in tobacco cells. J. Plant Physiol. $170,1434-1441$.

YAKIMOVA E. T., KAPCHINA-TOTEVA V. M., LAARHOVEN L. J., HARREN F. M., WOLTERING E. J., 2006. Involvement of ethylene and lipid signalling in cadmium-induced programmed cell death in tomato suspension cells. Plant Physiol. Biochem. 44, 581-589.

YAKIMOVA E., KAPCHINA-TOTEVA V. M., WOLTERING E. J., 2007. Signals transduction events in aluminum-induced cell death in tomato suspension cells. J. Plant Physiol. 164, 702-708.

YE Y., LI Z., XING D., 2013. Nitric oxide promotes MPK6-mediated caspase-3-like activation in cadmium-induced Arabidopsis thaliana programmed cell death. Plant Cell Environ. 36, $1-15$.

Yue W., Ming Q., Lin B., Rahman K., Zheng C., HAN T., QIN L., 2016. Medicinal plant cell suspension cultures: pharmaceutical applications and high-yielding strategies for the desired secondary metabolites. Crit. Rev. Biotechnol. $36,215-232$.

Zhang L. R., Xu Q. X., XING D., GaO C. J., XIOng H. W., 2009. Real-time detection of caspase-3like protease activation in vivo using fluorescence resonance energy transfer during plant programmed cell death induced by ultraviolet C overexposure. Plant Physiol. 150, 17731783.

ZHAO J. L., ZHOU L. G., Wu J. Y., 2010. Effects of biotic and abiotic elicitors on cell growth and tanshinone accumulation in Salvia miltiorrhiza cell cultures. Appl. Microbiol. Biotechnol. 87, 137-144.

ZHU L., CULLEN W. R., 1995. Effects of some heavy metals on cell suspension cultures of Catharanthus roseus. J. Environ. Sci. 7, 6065. 
KOSMOS Vol. 67, 2, 335-346, 2018

\author{
Klaudia Sychta, Aneta SŁomka, ElżBieta Kuta
}

Department of Plant Cytology and Embryology, Institute of Botany, Faculty of Biology, Jagiellonian University,

9 Gronostajowa Str., 30-387 Cracow

\title{
CELL SUSPENSION CULTURES AS A MODEL IN STUDIES OF PLANT TOLERANCE TO HEAVY METALS
}

\section{Summary}

Soil pollutants exert toxic effects on plants, animals and humans. Metallophytes, plants tolerant to heavy metals colonizing polluted areas, are being used to phytoremediation - cleaning up soil contaminated with heavy metals.

The use of plant cells in vitro cultures to study heavy metal toxicity and tolerance is a relatively new approach in research of metal toxicity. In this paper the usefulness of plant suspension cultures to study the impact of heavy metals on cells is presented alongside with the methods of obtaining suspension cultures, evaluation of cell viability, metal accumulation and detection of programmed cell death (PCD). The mechanisms by which cells of plant species tolerant to heavy metals develop resistance to metal toxicity are discussed. Cell suspension cultures appear to be a good model to study tolerance to heavy metals because they allow to estimate metal impact to a single cell in stable uniform conditions.

Key words: cell viability, heavy metals, metallophytes, programmed cell death, suspension culture 